\title{
Survey of Libraries in Colleges and Universities Which Are Not Giving Engineering Defense Training Courses
}

Mr. Mohrhardt is associate librarian of the Detroit Public Library and Chairman of the A.C.R.L. Committee on National Defense Services.

This factual study is based on the answered questionnaires received from twenty-three colleges and universities which are not offering engineering defense training courses. The majority of these institutions offer courses only in the liberal arts field.

Thus, it was not surprising to find incomplete answers to Parts I and II of the questionnaire. Part I considers "the library's service to industrial mobilization" and Part II, "reference service needs in industrial mobilization courses." The answers to Part III, "understanding the meaning of events," were in most cases comprehensive and illuminating.

An analysis of the answers to Parts I and II, though these are admittedly incomplete, are considered briefly in this study as they offer evidence of carefully prepared programs and of ideas which may be of value to other librarians. The answers to Part III are considered in more detail.

\section{Part I. The Library's Service to Industrial Mobilization}

Question I. "Do you perceive increased demands resulting from present industrial training courses?"

The curricula of most liberal arts colleges include only a few courses which might be considered pertinent to the immediate needs of national defense. In spite of this, however, 30 per cent of the colleges and universities answering this question reported increased demands upon the library for industrial defense training literature.

Most of these institutions are located in small, nonindustrial communities. Some, like Amherst, report that in their locale are "other adequate libraries more conveniently at hand than ours." Others report situations similar to Antioch College where "three members of Antioch's faculty are teaching courses in nearby cities but Yellow Springs (Ohio) is too small to have a program of its own. A handful of books are being bought for the teachers but students will be supplied with material in the public libraries of Dayton and Springfield." 
The answers to this question seemed to indicate that although increased local demands were slight as yet, there was an expected increase in momentum due to an impetus exerted by intangible forces in each community. There are indications that by the time this survey has come to publication these demands will not have diminished in intensity.

\section{Material Needed in Defense Training Courses}

Question 2. "Below is an attempt to analyze the specific types of material needed in defense training courses."

The following table has been compiled from the figures given in reply to this request.

The following additional subjects were listed by three librarians: "sources and supply of raw materials," "defense industries," "industrial education."

Question 3. "How would you spend the amount listed in question $2 \mathrm{C}$ (Column C, Table I) a. For more titles? b. For more copies of titles now held? What percentage of your entire collection is of value in meeting your demands for material on national defense subjects?"

In answer to the first part of this question five librarians replied that the money would be spent for more titles, one that additional money was needed for more copies, while fifteen gave no answer.

As to the percentage of the collection which is of value in meeting present demands estimates ranged from "practically none" to 20 per cent. One librarian commented that "in engineering practically the whole active collection is of at least potential value. In business, at a rough guess, perhaps io per cent. In most other departments a very small per cent, quite impossible to estimate."

\section{Expenditures for Defense Materials}

Question 4. "Have you increased your buying of books in vocational and technical subjects? Please give the amount spent last year and the amount you are

TABLE I

Number of Libraries Reporting Increased Demands in Various Subjects

\begin{tabular}{|c|c|c|c|}
\hline Subject & $\begin{array}{l}\text { Column A } \\
\text { Number of } \\
\text { Libraries } \\
\text { Reporting }\end{array}$ & $\begin{array}{c}\text { Column B } \\
\text { Estimated Number } \\
\text { of Additional } \\
\text { Volumes Needed } \\
\text { (Minimum and } \\
\text { Maximum) }\end{array}$ & $\begin{array}{c}\text { Column C } \\
\text { Estimated Cost } \\
\text { of Additional } \\
\text { Volumes Listed } \\
\text { in Column B } \\
\text { (Minimum and } \\
\text { Maximum) }\end{array}$ \\
\hline $\begin{array}{l}\text { Aeronautical design } \\
\text { Chemical engineering } \\
\text { Communications engineering, including radio } \\
\text { Electricity } \\
\text { Engineering drawing } \\
\text { Foundry practice } \\
\text { Industrial management } \\
\text { Internal combustion engines } \\
\text { Machine design } \\
\text { Machine shop practice } \\
\text { Map making } \\
\text { Materials inspection and testing } \\
\text { Mathematics } \\
\text { Metallurgy and metallography } \\
\text { Navigation (surface and aerial) } \\
\text { Optics } \\
\text { Ordnance } \\
\text { Production engineering and supervision } \\
\text { Shipbuilding and naval arhitecture } \\
\text { Structural design } \\
\text { Tool engineering } \\
\text { Welding (design and supervision) }\end{array}$ & $\begin{array}{l}8 \\
6 \\
7 \\
4 \\
5 \\
1 \\
7 \\
2 \\
3 \\
3 \\
2 \\
5 \\
3 \\
5 \\
4 \\
7 \\
1 \\
4 \\
2 \\
2 \\
2 \\
2 \\
1 \\
1\end{array}$ & $\begin{array}{l}\text { I0 to } 300 \\
10 \text { to } 25 \\
5 \\
20 \text { to } 25 \\
15 \\
\text { 10 to } 20 \\
\text { I0 to } 25 \\
\text { I0 } \\
5 \\
10\end{array}$ & $\begin{array}{l}\$ 45 \text { to } \$ 600 \\
45 \text { to } 75 \\
25 \\
50 \text { to } 90 \\
45 \\
40 \text { to } 50 \\
40 \text { to } 75 \\
40 \\
20 \\
35\end{array}$ \\
\hline
\end{tabular}


currently spending. Please indicate the source of these funds."

In reply to the first part of this question five librarians indicated an increase in the purchase of books on defense subjects, ten reported no increase, and eight did not answer. The amounts spent ranged from $\$ 50$ to $\$ 10,773$ and the percentage of increase ranged from 20 to 500 per cent. The university reporting the $\$ 10,773$ figure supplied the following explanation for this unusually large amount :

For current teaching needs in the seven departments closely identified with defense, there was an increase in expenditures from $\$ 1,283$ in 1939 to $\$ 9,087$ in 1940 . Some of this increase was due to the defense program. For the years 1939 and 1940 , an additional sum of $\$ 8,825$ was spent for expensive and out-of-print sets in the fields referred to above. On funds outside the library budget, specific departmental operating allotments, there was an increase in expenditures for technical books for office and laboratory use and for texts in industrial education. In 1939, \$960 was spent for such materials, and in $1940, \$ 1,686$. The major part of the increase was for books in industrial education.

As to the sources for these funds for increased buying three reported them as coming from specific book funds, five from general funds, and fifteen gave no answer.

Question 5. "Have you been able to obtain additional funds for the specific purpose of increasing your holdings in vocational and technical materials?"

Four librarians reported that they were able to secure additional funds in amounts varying from $\$ 20$ to $\$ 287$. The librarian reporting the large amount mentioned in the previous question did not find it necessary to ask for additional funds "since sufficient general funds were available."
Seven were unable to secure more funds and twelve did not answer.

\section{Personnel}

Question 6. "Are you limited in meeting known or possible needs by lack of enough trained personnel or of specialized personnel?"

Six reported a hampering of efforts due to lack of personnel but five of these added that this was an old problem and not due to increased demands for defense material. Five librarians expressed a desire for specialized personnel and ten others answered that there was no immediate need for either more or specialized personnel.

\section{Cooperative Measures}

Question 7. "Please describe any cooperative measures you have undertaken with other libraries or your state library agency."

This question was answered by eight librarians and most of them reported that no special measure had been taken as it had always been their policy to cooperate with other institutions, industrial firms, and individuals. Four of those answering did, however, mention a noticeable increase in the number of interlibrary loans requested of them and an increase in the number of requests for extensive bibliographies.

Question 8. "Have you installed any special services to meet industrial and industrial training needs?"

Eleven reported that no special services had been inaugurated at present as there had been no need for them. They all were willing to meet this problem when the need arose. The six reporting "yes" to this question revealed a wide diversity of services. For example, one large uni- 
versity is supplying technical information to chemical and industrial factories in its state and to faculty members who are serving as consultants on defense projects; another reports that library privileges have been granted to the officers of a nearby air corps training school and, when needed, to the civilian instructors at this school; others report special vocational and industrial training exhibits in the library and classrooms and reserve collections for the use of students enrolled in Civil Aeronautics Authority training courses.

\section{Part II. Reference Service Needs in Industrial Mobilization Courses}

Question I. "What changes have taken place in the curriculum and how have these changes affected the library?"

Forty-eight per cent of the libraries answered this question reporting curriculum changes with comments upon the effect of these changes. The following excerpts from their comments are indicative of the situations which exist in various localities.

Albion College writes:

... We contemplate both a shift in subjects and a shift in method to meet the emergency. We expect to realize the greatest change in the various science departments and in economics. In certain fields our book collection is inadequate and we are working with the faculty and administration to learn what the probable changes will be in the curriculum, in order that we may be prepared to meet the need, as completely as our finances will permit.

\section{Alma College reports:}

New citizenship courses: I. Orientation study in social science-Freshmen. 2. Studies in American life. The American scene. 3. Detailed study of the American Ideaincluding international relationships, war, federal union of nations, etc. 4. Seminar courses in democratic living. There is a reading shelf in the library for all of these courses.

The American University, Graduate School, offers new courses "on management in relation to the current emergency and problems of emergency and post-war reconstruction."

\section{Brooklyn College writes:}

We are this term giving for the first time the following courses especially designed to meet the needs of defense: economics of defense and war, ballistics. ... We have just received a donation of three hundred dollars for books which will be used in a special honors course on American civilization soon to be initiated.

\section{Columbia University states:}

Curriculum changes to date are more noticeable in business than in other fields. There, more emphasis is being placed on instruction in economic geography, on the problem of raw materials, and defense industries. Increased emphasis is also noticed on problems of personnel and labor. The library is naturally called upon to build up and organize material on the defense activities of the government, to collect data on raw materials and key industries, and also on labor problems and labor policies. The reference service is called upon for more information on various phases of national economy as affected by the defense emergency such as prices, foreign trade, shipping, etc.

Indiana University reports the following curriculum changes as a result of national defense problems:

I. Problems of business and industrial mobilization. 2. Military science and tactics. Course in aeronautics. Flying. 3 . Propaganda analysis. 4. N.Y.A. resident training center. 5. Course in shop work in the university high school. . . F For the 
history department a special fund has been appropriated for books, pamphlets, periodicals and newspapers on current history. ... For the propaganda analysis course a special sum of $\$ 60$ has been appropriated for collecting material. For the industrial mobilization course, sixteen books have been purchased during the last eight months. Five copies of each were added to the library. Pamphlets that deal with strategic materials are assembled. These are to a large extent government publications. Books on other allied subjects are being bought liberally.

Northwestern University lists the following defense courses:

South American economy, Hispanic-American history and the United States, the contemporary mind, education and the contemporary mind, aeronautical science, geographic problems of national defense, political geography of the world, totalitarianism, and education and the pressure groups.

Washington and Lee University is offering the following new courses which "have direct bearing upon preparation for national defense ... military history and policy, military explosives and chemical warfare, military geology and topography, military photography, and citizenship and defense."

Question 2. "Please describe any cooperative measures you have undertaken with governmental defense agencies and defense industries."

Fifteen libraries have listed their resources in Cannon: Guide to Library Facilities for National Defense. These libraries have also checked many other lists and bibliographies for other libraries and defense industries in their states. Four libraries report that they have supplied faculty members engaged in outside defense work with needed materials. Some of these faculty members are serving as consultants with governmental agencies and others as consultants with industrial firms.

\section{Dartmouth College reports:}

The department of physiological optics is cooperating with and conducting experiments for the armed services. This is the most conspicuous case locally. There is an official and active local group studying the relation of the college to the present emergency, and it serves as a clearing house for all information and activity. When assistance has been asked, response is generous and prompt.

\section{Part III. Understanding the Meaning of Events}

Question I. "Please check the following list of subjects for an estimate of the demands from individuals and groups." The answers to this request have been incorporated into Table II, which follows.

Two libraries reported increased demands for material on civil liberties, and others reported an increased demand for material on air raid precautions and personnel and management.

In commenting on the supply of books covering the subjects listed in Table II ten libraries mentioned that their present stock was adequate and four others stated that their present funds were inadequate to purchase up-to-date material.

The following comments are typical of those received in answer to this question:

(Albion College) Some of these subjects have regularly received considerable stress in the curriculum. In those subjects we have not noticed a great increase of attention. We have noticed a greater interest on the part of the students in material contributing to an understanding of present events than we have on actual technical material. 
(Amherst College) Apart from the interest which is thus generated in the classroom we recognize an obligation to the college community as a whole in trying to make possible the fullest freedom of thought

TABLE II

Demands for Material on Current Problems

\begin{tabular}{l|c|c|c}
\hline \hline & \multicolumn{3}{|c}{ Demands } \\
\cline { 2 - 3 } \multicolumn{1}{c|}{ Subjects } & $\begin{array}{c}\text { Number } \\
\text { of } \\
\text { Libraries } \\
\text { Reporting } \\
\text { No In- } \\
\text { crease }\end{array}$ & $\begin{array}{c}\text { Number } \\
\text { of } \\
\text { Libraries } \\
\text { Reporting } \\
\text { Some In- } \\
\text { crease }\end{array}$ & $\begin{array}{c}\text { Number } \\
\text { of } \\
\text { Libraries } \\
\text { Reporting } \\
\text { Great In- } \\
\text { crease }\end{array}$ \\
\cline { 2 - 3 } & & & \\
\hline $\begin{array}{c}\text { Aims and character of } \\
\text { the totalitarian pow- }\end{array}$ & 3 & 8 & 4 \\
ers & 3 & Io & 4 \\
$\begin{array}{l}\text { International coopera- } \\
\text { tion }\end{array}$ & 2 & 9 & 4 \\
$\begin{array}{c}\text { Military and economic } \\
\text { problems }\end{array}$ & 3 & 6 & 5 \\
$\begin{array}{l}\text { Propaganda methods } \\
\text { Trade relations }\end{array}$ & 5 & 9 & I \\
$\begin{array}{l}\text { Unemployment } \\
\text { Youth problems }\end{array}$ & 5 & 9 & 0 \\
\hline
\end{tabular}

and opinion by having available books and pamphlets bearing on all sides of current domestic and international problems. To this end we are spending more money than usual for the acquisition of published materials listed (in Table II) and there has been observable an increased demand for materials on propaganda. In addition we have attempted to bring together a representative body of material on Canada and on Latin America, having in view the problem of hemisphere solidarity.

\section{Pamphlet Materials}

Question 2. The answers to this question on the use and value of pamphlets are given in Table III. These questions were answered by two thirds of the libraries receiving the questionnaire.

\section{Responsibility of Library}

Question 3. "What do you think about the responsibility of the library for promoting study and understanding of the present crisis? Can the library make a significant contribution on its own? Should librarians adopt a positive and vigorous attitude in trying to interest people concerning the problems around them?"

In answer to all of these questions nine librarians assumed a positive attitude and two a negative one. The following excerpts are representative of the opinions which were expressed in reply to these questions.

I. We in the library believe that we have a special responsibility at the present time to provide the best information possible on current developments through the best newspapers, magazines, pamphlets and books. We call student attention to these in special talks. We offer special displays. We have a book forum for student discussion of new books. We do firmly believe that librarians should adopt a positive and vigorous

TABLE III

Use and Value of Pamphlet Materials

\begin{tabular}{|c|c|c|c|}
\hline & Yes & No & $\begin{array}{l}\text { As Supple- } \\
\text { mentary } \\
\text { Material }\end{array}$ \\
\hline $\begin{array}{l}\text { Do you find that pamphlet } \\
\text { materials help to meet the } \\
\text { demand in these fields? }\end{array}$ & I5 & $\circ$ & \\
\hline $\begin{array}{l}\text { Are they satisfactory substi- } \\
\text { tutes for books? }\end{array}$ & 4 & 4 & 7 \\
\hline $\begin{array}{l}\text { Do you duplicate pamphlets } \\
\text { freely? }\end{array}$ & 6 & 9 & \\
\hline $\begin{array}{l}\text { Do you make any special ef- } \\
\text { fort to circulate them? }\end{array}$ & 9 & 5 & $\begin{array}{l}\text { (used only as } \\
\text { reference ma- } \\
\text { terial) }\end{array}$ \\
\hline
\end{tabular}

1 "Fields" refers to the subjects mentioned in Table II.

attitude in trying to interest people concerning the problems around them .... we have been stressing special displays on "Building Our World"-with books and magazines on music, art, travel and other cultural interests that suggest permanent foundations for rich living. . . .

2. Our local situation is such that the college library cannot hope to assume primary responsibility for promoting the study and understanding of the present crisis. However, we have clearly recognized, and have acted upon our recognition of our 
obligation to have available the raw materials for such study.

3. We consider it our primary function to supply titles suggested by instructors or called for by students, and others which in our judgement would be useful. We call attention to what we have by exhibits and verbal suggestion. ...

4. I regret that our replies are so predominantly negative (for question 3 ). Most of the questions have no conceivable connection with a university library.

5. These questions have been especially designated by department heads in the ... Libraries as even more silly than many of the others.

6. The library attempts to promote study and understanding of the present crisis by displaying collections of books. These collections are sometimes general books on the subject of democracy, international problems, or allied subjects. The library correlates its display of books with the activities on the campus....

7. In a university library the librarian should surely make good use of whatever free material that is now made available and purchase widely in general fields not covered by any department of instruction. Books on travel and description and books dealing with such questions as democracy and Latin America; general essays dealing with points of view on world affairs-all fall within the field of general interest. ...

8. Traditionally our American libraries do not take sides. Actually, of course, they do, as is definitely shown by Esterquest's recent article in the Wilson Bulletin. In 1936, in an article in the Library Journal (v. 6I, p. 185) I wrote, "Perhaps as the pendulum of history swings through its appointed course it may develop that to preserve the tradition of the civilized world, free and untrammeled, librarians may, paradoxically, have to be militant in their opposition to a social order which threatens their freedom." I still stand by this statement and paradoxically, I still believe in the principle of free expression on all sides of controversial issues. We are, after all, libraries in a democracy, and as such, I believe we are justified in weighting our service and efforts in favor of democracy, because if our democracy goes down, the democratic principle of free expression goes with it.

9. The library can and should make a significant contribution to the study and understanding of the present crisis. It has been contributing from the beginning in supplying scientific and technical information. It should make available and call attention to pamphlets, books and other materials dealing with contemporary questions. Participation in the intellectual life of the people should be more active than has been typical of the past. 